\title{
The Economic Implications of Global Water Scarcity
}

\author{
Arthur S. Guarino ${ }^{1 *}$ \\ ${ }^{1}$ Rutgers University, Department of Finance and Economics, Newark, New Jersey, USA \\ *Arthur S. Guarino, E-mail: Arthur.Guarino@hotmail.com
}

Received: January 14, 2017 Accepted: February 28, 2017 Online Published: February 16, 2017

doi:10.22158/rem.v2n1p51

URL: http://dx.doi.org/10.22158/rem.v2n1p51

\begin{abstract}
Water, like any other natural resource, is vital to a nation's economic growth and existence. Without adequate water supplies a nation will face severe economic problems as well as social unrest and political instability. The current problem many nations face is their dwindling water supply. The aim and purpose of this paper is to examine the economic impact of global water scarcity on both developed and developing nations. This paper will also examine how a lack of clean water will hurt a nation's economic growth and its ability to be a viable player in global trade and be able to provide for its people. This study will also look at the causes of water scarcity and also how the problem can be rectified.
\end{abstract}

\section{Keywords}

water scarcity, agriculture, water footprint, groundwater depletion, market failure, virtual water, water pollution

\section{Introduction}

Water is a resource that is vital to our existence, but too often has been taken for granted. Water is an important economic resource that if nations and societies allow to be wasted, it is then certain they will eventually collapse. Water's economic contribution is immeasurable since it is used in agriculture, transportation, and industry. Without a sustainable supply of water, economic catastrophe will soon occur. The problem that many nations face is the dwindling supply of water that will affect their population in the long and short term ranging from economic slowdown to starvation. According to University of Twente (Netherlands) Professor of Water Management, Arjen (2016), two-thirds of the world's population (4.0 billion people) live with severe water scarcity at least one month of the year. He also stated that half a billion people around the world face severe water scarcity throughout the whole year (Hoekstra, 2016). Water scarcity not only affects developing nations, but also economically developed countries.

The aim and purpose of this paper is to examine the economic impact of global water scarcity on both developed and developing nations. This paper will also examine how a lack of clean water will hurt a 
nation's economic growth and the ability to be a viable player in global trade and be able to provide for its people. This paper will also look at the causes of water scarcity and also how the problem can be rectified.

\section{Method}

\subsection{Causes of Water Scarcity}

There are numerous reasons for water scarcity around the world. While policymakers, scientists, and researchers may not agree on every reason for water scarcity, there are a number of reasons many feel are causing the problem to escalate globally.

First, there is the problem of the uneven distribution of water. This results when a population lacks the proper and sufficient financial resources to fully and correctly utilize adequate water sources. This will often result in an unequal and inequitable distribution of water. This can be due to political and ethnic conflicts that occur in many areas of the world such as vast parts of sub-Saharan Africa (The Water Project, 2016). Uneven distribution of water is also connected to the size of a firm's or organization's water footprint. The water footprint is a recent tool measuring consumptive water use and the volume of water polluted (Hoekstra, 2014). The concept of water footprint is concerned with the fact that water is not being fully returned to the environment or perhaps not in a clean state. This means that industries such as mining, manufacturing, and agribusiness are using more water in the production process while denying a nation's population the use of clean, drinkable water. This is also seen in the Middle East in which there is an increase in water-intensive projects such as golf courses which have a large water footprint. For example, in a 2007 report released by the consulting firm, Klynveld Peat Marwick Goerdeler (KPMG), the estimated use of water for each golf course in the Middle East is an average of 1.16 million $\mathrm{m}^{3}$ per year, reaching 1.3 million $\mathrm{m}^{3}$ in Dubai, which is sufficient to cover water consumption for 15,000 people (Hussein, 2011).

Another severe cause of water scarcity is the high use of irrigation systems such as canals, aqueducts, and reservoirs for industry and agriculture. These irrigation systems are mainly used for agriculture and transporting water to cities and other population centers. Agriculture uses the largest portion of the globe's fresh water consumption for growing and maintaining crops and fruit trees. The United Nations has stated that agriculture uses approximately 70 percent of all water withdrawals while industry uses 22 percent and domestic activities about 8 percent (Hodgson, 2010). However, approximately 60 percent of the use by agriculture is wasted due to leaky irrigation systems, inefficient application methods, and crop cultivations which are too thirsty for the land where they are grown (World Wildlife Fund, 2016). This makes a serious problem worse by exhausting rivers, lakes, and underground aquifers. In parts of the world that have a hot climate, the amount of water necessary for one hectare of irrigation is approximately one liter per second for every second in a single day (Tickner, 2016). Compounding matters, irrigators usually pay a minute fraction of the price of water charged to residential, commercial, and industrial users which translates into a low-value use (Hertel et al., 2013). 
There is also water lost due to poor system maintenance. For example, the United States loses an estimated 2.1 trillion gallons annually, or 16 percent of water it uses daily, through outdated and leaky infrastructure (Paulson, 2015).

A third massive cause of water scarcity is the increasing global population which ultimately depends heavily on a continuous and stable water supply. While the global population is not growing at the fast rate some analysts had predicted, it is still growing and there is an increasing demand for water. The problem is that water is now regarded as a scarce resource in many parts of the world. It has been estimated that global water consumption is growing at two times the global population growth rate (Chowdhury, 2008). One estimate has the world population peaking at 9 billion by 2070 (Young, 2001), which means that global water consumption must be enough to satisfy the needs of twice that many people. Both developed and developing nations are facing problems meeting the water demands of its people. For example, estimates state that the average person in developed countries use 200 to 800 liters per day of water while in developing nations there is a need of 60 to 150 liters daily (Fogden \& Wood, 2009). In certain countries, the situation is dire. For example, Yemen's population is growing and its demand for water is increasing which means the country must take resources from other areas in order to satisfy the need. Yemen must address key issues in order to improve its water management situation. Among these key issues are a decaying water infrastructure and inefficient irrigation systems (Stratfor, 2014). It has been estimated that approximately 1.5 percent of Yemen's Gross Domestic Product (GDP) has been lost to groundwater depletion while 2.4 percent is lost by its failure to deal with water sanitation issues (Stratfor, 2014). Yemen's water table is dropping by up to six meters per year and by 2025, Sanaa, Yemen's capital, could be the first capital in the world to run out of water (Odhiambo, 2016). While the global population has more than doubled in the last 50 years, a shift has occurred in which 41 percent of the world's population lives in river basins that are under water stress (World Wildlife Fund, 2016).

Compounding the problem of a growing world population is the increasing urban populace. Currently, over 60 percent of the global population live in urban areas thereby increasing the need for sustainable water (Tickner, 2016). Cities and towns are growing in population around the world and this means a difficult challenge for already overburdened water infrastructure systems in many nations. For example, in 1970, 38 percent of the Arab population lived in cities but by 2005 it had increased to 55 percent and is expected to surpass 60 percent by the year 2020 (United Nations, 2009). On a broader scale, by 2020, 55.6 percent of the world's population will live in cities, which is an increase from 46.8 percent in 2000 (Hodgson, 2010). Increases in urban population will mean greater demand for water in agriculture, industry, and daily living requirements.

Another major cause of water scarcity is overuse. Water overuse is tied into the extended use on animals, crops, humans, or recreational activities. Water scarcity is best defined as the point at which the aggregate impact of all users impinges on the supply or quality of water under prevailing institutional arrangements to the extent that the demand by all sectors, including the environment, 
cannot be satisfied fully. Water scarcity is a relative concept and can occur at any level of supply or demand (Muta'a, 2012).

The problem is that overuse occurs and it has a domino effect within various countries and regions. An example of the overuse of water is that it can cause water scarcity, which leads to increasing heavy grain imports in many smaller countries thereby eventually occurring in larger nations including China and India (Wikipedia, 2016). There is also the over-pumping of water in nations such as China, India, and the United States through the use of powerful diesel and electric pumps that is causing water tables to fall (Wikipedia, 2016). In the Arabian Peninsula, the total annual water withdrawal is $271.5 \mathrm{~km}^{3}$, which is approximately 7 percent of world withdrawals (Odhiambo, 2016). In dry areas, such as the Arabian Peninsula, it may be very difficult to replenish this water and there is no clear-cut substitute for it. Overuse also occurs in particular industries such as breweries, the growing of rice which is a $\$ 5$ billion industry in California (Douglas, 2015), clothing manufacturing, and the making of semiconductors. In Saudi Arabia, the overuse of water is regarded by some as being a very serious problem. Saudi Arabia is now third behind the United States and Canada in water usage per capita in which it has a level of consumption of approximately 250 liters per capita daily (Drewes, 2012). With a combination of a low water tariff and lack of government supervision of its water supply, the Saudis have little to no incentive to conserve its dwindling water supply (Drewes, 2012). In West Asia, the problem is also very dire. Due to an increase in the demand for water resulting in reduced per capita availability, West Asia is faced with diminishing water quality because of seawater intrusion, groundwater over-exploitation, the depletion and salinization of aquifers, and rising pumping costs (Jena, 2016).

Water pollution also plays a major role in diminishing the world's water supply. Water pollution has numerous sources such as fertilizers and pesticides that are runoffs from farms, waste from industrial production such as oil and chemicals, and untreated human waste. Greenpeace International reports that about 70 percent of China's lakes, rivers, and reservoirs are polluted (Hodgson, 2010). Not only is surface water susceptible to pollution but also subsurface water due to pollutants sinking below ground. This is often due to a lack of proper sanitation methods. For many developing nations, the lack of sanitation can be a key contributor to water pollution and substantially hurt their economic development. For example, the Water and Sanitation Programme (WSP) reported in 2006 that Indonesia's sanitation system was so poor that it cost the country $\$ 6.3$ billion, or 2.3 percent of its GDP (Chowdhury, 2008). The WSP also found that Africa lost an estimated 5 percent of its GDP due to illness and death due to poor water and the lack of proper sanitation facilities (Chowdhury, 2008). However, pollution should be alleviated because for every $\$ 1$ spent on water and sanitation there is a return of $\$ 8$ to $\$ 10$ in economic development in poor nations (Tickner, 2016). This can help developing countries become growing economies in the long run.

Another major reason for water scarcity are frequent droughts occurring worldwide. Climate change has been cited as causing temperatures to increase therefore leading to more water evaporation and to 
more frequent droughts. With the continuous and increasing expulsion of carbon dioxide and numerous greenhouse gases into the earth's atmosphere, this has resulted in diverse weather patterns and the increasing frequency of droughts. With the atmosphere heating up this has caused glaciers and packs of snow to melt and diminishing the earth's supply of fresh water. Also, with the rise of extreme weather patterns and flooding there can be heavy damage to infrastructure used in the treatment, transportation, and delivery of water (ASTHO, 2015). In the long term, this will make water scarcity a larger problem for many countries. Nations such as Pakistan are already experiencing the combination of a growing human population and frequent droughts that is especially hurting its ability to grow crops. To make matters worse, India is diverting Pakistani water and has built more dams which will further worsen Pakistan's water shortage (Khan, 2015). In other parts of the world, droughts have had a severe impact on the economies of various nations. For example, in 2006-2007 a drought in Australia reduced at least 1 percent of its GDP (World Economic Forum, 2011). According to the World Bank, in China in 2013, water shortages cost it 2.3 percent of its GDP due mainly to health losses (The Economist, 2013). In the United States, it is estimated that by 2020 water shortages will cost taxpayers in California $\$ 1.6$ billion per year (World Economic Forum, 2011). There is also the concern of super droughts and mega droughts in the United States which would affect and devastate the American Southwest and Central Plains (ASTHO, 2015).

One other cause of water scarcity is governmental access. The problem in certain parts of the world is that those nations ruled by dictators have strict control over access to water for farming and human use. These dictatorships use access to water as a way to control their people and enforce their allegiance. But there are other nations that do not have dictatorships but instead have poor governmental policy regarding the allocation and distribution of water for farming and drinking. While these policymakers may have the best of intentions, their decision-making prowess leaves much to be desired. Poor decision-making could lead to market failures and the need for improved strategies in order to better manage scarce and dwindling water sources. A report by the World Wildlife Fund stated that: The management of water, for ensuring the delivery of basic services to citizens, for economic growth, and for maintaining healthy water environments, is ultimately the responsibility of governments. Yet, low prioritization of water management and poor co-ordination within government ministries often mean that too many water resources are over-committed and undervalued. As a consequence, communities and economies around the world suffer from water shortages, poor water quality and degraded environments (Cartwright, 2009).

\section{Result-Economic Impact of Water Scarcity}

Global water scarcity can have a severe impact on the economies of many, if not all, nations. One area that will be impacted is bilateral international trade. For those nations experiencing water scarcity they will tend to produce less agricultural goods and fewer manufactured products and will have to import greater amounts of each but at significantly higher prices (Hertel et al., 2013). In this case, these 
nations will be at a severe disadvantage since they will have to borrow more funds at higher interest rates thus causing financial deficits that will not improve over time. This will also cause a dangerous imbalance in the global trade market causing certain nations to go deeper into debt while others become wealthier over time. Financial projections state that huge food and agricultural trade deficits due to water stress could occur in South Asia at $\$ 1.35$ billion while the Middle East and North Africa (MENA) region will have a deficit of $\$ 0.6$ billion and nations such as China will see a gap of $\$ 1.08$ billion and India of $\$ 0.44$ billion (Hertel et al., 2013). In this case, trade occurs in the water used in the process of the good or product and is known as virtual water (Klepper, 2007). Currently, there are approximately $1,000 \mathrm{~km}^{3}$ of virtual water internationally traded every year (Klepper, 2007).

Another area of economic impact is to businesses worldwide. Industries and businesses use large amounts of water in order to manufacture goods and products and in certain cases to provide services. For example, Chile's copper production uses substantial amounts of water and its key mining area is in the northern region next to the Atacama Desert which is regarded as one of the most arid areas on the planet. This has caused water to not only become a more expensive commodity but also one that local farmers are battling for water rights (Cartwright, 2009). Many businesses are now taking into consideration the availability of water as a vital natural resource when making decisions on locations for investments or manufacturing. Water for numerous companies was taken for granted for many decades since it was abundant, cheap, and generally clean. But now due to threats of increasing water pollution and water scarcity on a global scale, many firms are paying more attention to water access than ever before. This also has a ripple effect on municipalities since the loss of firms due to water scarcity means declining tax revenues, job loss, and shrinking economies.

The lack of water also has an impact on the generation of energy and its cost. Nearly all sources of energy production need water. Providers of energy sources such as oil, coal, hydroelectric power, and nuclear energy all use water as a way to clean, extract, transport or cool down their product (Ross, 2016). The World Bank reported in 2014 that 50 percent of global power utility and energy companies experienced water connected impacts on their businesses in the preceding five years in which 66 percent reported water as a key and substantial risk to their future operations (Ross, 2016). In Switzerland, energy costs are expected to increase since cold water, which is vital to cooling its nuclear power plants is dwindling due to declining water supplies from glaciers (Cartwright, 2009). It has been predicted that Switzerland will see a 25 percent decrease in nuclear power generation by the year 2020 since water supplies will decline and eventually cause energy prices to increase (Cartwright, 2009). Water shortages in Italy and Australia have also caused energy shortages and will eventually cause energy costs to rise (Cartwright, 2009).

The lack of clean water also has health implications which can have economic ramifications. When there is polluted drinking water, then there is an increased chance for the spread of diseases such as malaria, cholera, diarrhea, and dysentery. In developing countries, such as Nigeria, the lack of clean drinking water increases the chance of the spread of disease and the odds of adults and children dying 
than in developed countries. This means that developing nations, rather than using resources to expand their economies, must do what they can to enhance and maintain their water infrastructure. Nigeria also has the problem of weak sanitation which has a direct impact on its labor force since much of its populace in the working class as well as children lose thousands of man-hours to communicable diseases (Muta'a Hellandendu, 2012). The human cost in Nigeria is immeasurable, based on statistics by UNICEF in which more than 2 million children under the age of 5 years old die annually from diarrhea and pneumonia-related illnesses (Muta'a Hellandendu, 2012). This catastrophe will eventually have long-term economic implications for Nigeria since a growing population is a necessary aspect of economic growth for any country.

Tourism will also be deeply impacted by water scarcity. For many countries, tourism is a key industry and a source of substantial revenue. While for many tourism is regarded as a luxury item, in numerous developed nations tourism is a vital industry. Not only is water crucial for recreational uses involving lakes and rivers, but also for swimming pools and recreational parks. In the United States, the popularity of water-themed recreation parks is growing and attendance is increasing. There is also the growing use of water for such tourist attractions as golf courses. A clear example of this is the state of Nevada in the United States. Nevada has 45 golf courses, used by one-third of all its tourists, providing more than $\$ 1$ billion in annual revenues for the state, employing more than 4,000 people (Repetto, 2012). In order to maintain Nevada's golf courses in the oppressive heat, it needs substantial amounts of water to keep its courses green and artificial lakes full. Halfway around the world, the Arabian Peninsula is attracting an increase in tourism through its golf courses. However, this requires a heavy amount of water. For example, an 18-hole golf course in a Mediterranean sand dune system in the Arabian Peninsula uses between 0.5 to 1 million $\mathrm{m}^{3}$ of fresh water annually (Odhiambo, 2016). The ironic aspect to both of these situations is that if it were not for water irrigation systems, the pumping in of massive amounts of water from faraway places, and the technology available to accomplish such a feat, these courses would not normally exist since they are really desert locations.

If there is one major industry that will be severely impacted by global water scarcity it is agriculture. Every nation on the globe will be impacted by water scarcity since all nations, in one way or another, is involved in agriculture, whether as an importer or exporter. Water scarcity's effect on agriculture most often comes in the form of droughts which ultimately has a huge impact on households, restaurants and eating establishments, large supermarket chains, and corner grocers. California, which is regarded as a key food producer for the United States and the world, has had droughts in which the estimated cost on agriculture are as high as $\$ 1.5$ billion annually which is more than two-thirds of the total statewide economic cost (Ross, 2016). California farmers are huge users of water since agriculture accounts for 80 percent of water consumption in the state (Tabarrok, 2015). Making matters worse, as the world's population increases, there will be the demanding need to feed everyone. However, if water scarcity continues to worsen, keeping up food production will be an increasingly difficult task. If there is a lack of water, then this could lead to political and social unrest. The United Nations has warned that political 
turmoil, social unease, civil war, and terrorism could result from a lack of food unless production increases by 60 percent by the year 2050 (Seametrics, 2015). If food prices climb at high rates due to insufficient production because of water scarcity, then unrest, both social and political, will increase on a global basis. Globally, farmers are regarded as the key managers of water since they employ 80 percent of the water that society uses (Tickner, 2016). The World Bank reports that water scarcity could lead to a high risk of conflict and that increasing food prices could incite latent conflicts while driving migratory forces (Sahai, 2016). In certain parts of the world, the economic impact of water scarcity on agriculture has already been felt. For example, in the northern sector of the Jordan Valley, water scarcity has reduced the area planted, income, and labor at the regional level, which has impacted cropping intensity and cultivation (Hussein, 2011).

The following chart is a small representation of water scarcity consequences in the United States affecting its agricultural industry within a relatively short time frame.

Table 1. Impact of Water Scarcity in the United States on Agricultural Industry

\begin{tabular}{|c|c|c|}
\hline Location & Date & Impact of Water Scarcity \\
\hline California & 1987 to 1992 & $\begin{array}{l}\text { Farmers suffer losses of } \$ 800 \text { million while landscape and garden } \\
\text { industry loses } \$ 460 \text { million and eliminate } 5,600 \text { jobs }\end{array}$ \\
\hline California & 2009 & $\begin{array}{l}\text { Avocado farming revenues reduced by nearly } \$ 13 \text { million due to } \\
\text { water shortages and increased water costs }\end{array}$ \\
\hline Texas & 2011 & $\begin{array}{l}\text { Losses of } \$ 7.62 \text { billion due to drought: } \$ 3.23 \text { billion from livestock, } \\
\$ 2.2 \text { billion from cotton, } \$ 736 \text { million from corn, and remainder from } \\
\text { hay, wheat and sorghum }\end{array}$ \\
\hline Kansas & 2012 & $\begin{array}{l}\text { Cost of corn increase due to drought-induced crop losses causing } \\
\text { cattle prices to drop from } \$ 1.60 \text { /pound to } \$ 1.20 / \text { pound }\end{array}$ \\
\hline California & 2013 & $\begin{array}{l}\text { Sugar cane prices drop from } 32.4 \text { cents per pound in } 2012 \text { to } 21.5 \\
\text { cents per pound due to drop in rainfall average }\end{array}$ \\
\hline Colorado & 2013 & $\begin{array}{l}\text { Potato acreage in San Luis Valley decreases to } 49,700,11 \text { percent less } \\
\text { than in } 2012\end{array}$ \\
\hline
\end{tabular}

Perhaps the most dangerous aspect of water scarcity is the damage it will do to future economic growth. With water scarcity, there will be a loss of jobs since industries such as agriculture, food processing, and manufacturing will not have enough water in order to make needed goods and products. Nations that do not have enough water will not be able to sustain their economy in the long-term due to higher degrees of volatility of commodity prices, reduction in manufacturing in areas where water is scarce, revision of import and export strategies, and flight of capital to different nations that have water surplus. Firms will have to revise their manufacturing processes, which will affect their industrial production 
and use of technologies. In the long run, this will mean a shift that will, hopefully, be able to better deal with the problem of water scarcity. But in the short-term, this will mean a shifting of financial capital that some industries and nations may not be able to perform.

As seen in the graph below, it is predicted that as the access to safe drinking water decreases over time, the level of access that corresponds to negligible growth is expected to be reached by 2050 at the latest (Fogden \& Wood, 2009).

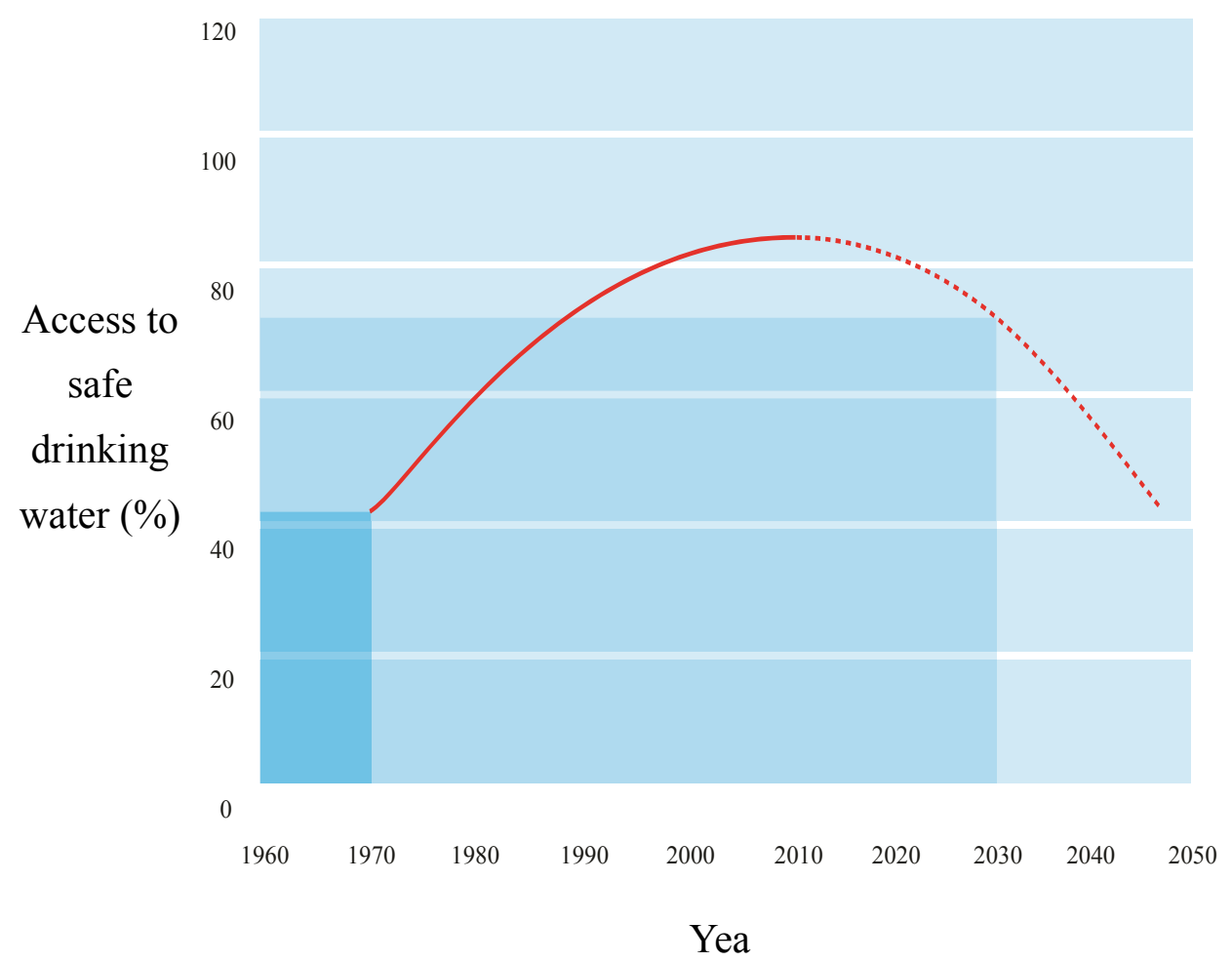

Figure 1. Projection of Global Population Accessibility to Safe Drinking Water as a Percent

As pointed out by Fogden and Wood (2009), if there is water scarcity in developing nations and emerging markets, then the following could occur:

- $\quad$ Rising labor costs fueled by increases in drinking water prices;

- $\quad$ Lower productivity due to higher incidence of disease among the working population;

- Greater investment risks;

- Loss of export markets in the emerging and developed world.

In the developed nations, Fogden and Wood (2009) also felt that economic growth would result in:

- Loss of export markets in the emerging markets and developing world;

- Decline in travel and tourism;

- $\quad$ Rising labor costs in agriculture, manufacturing, and labor-intensive industries;

- Lower productivity due to increased health burdens.

Ultimately, water scarcity has many important implications and dire consequences on a global scale. 


\section{Discussion-Possible Ways to Rectify Water Scarcity}

Even though water scarcity is a dangerous global problem with economic implications, there are numerous possible ways to rectify the situation. One possibility is increasing water storage infrastructure such as the use of dams. Dams can act as a way to combat the problem and make water more available in many locations suffering from water shortage. But these dams must be built in an effective manner in order to improve water management. In Iran, they are experiencing negative effects of large-scale dam projects that lack proper regional planning (Hooley, 2016). While dams can be useful in water storage they can also be seen as strategic targets and weapons of war. For example, control over water resources is important to the Islamic State's (ISIS) strategy of the creation of a caliphate in Iraq and Syria (Heinrich \& Pedraza, 2016).

Another method to alleviate water scarcities would be the harvesting of rainwater. This has been done in numerous places around the world and is a way to collect, put into storage, and then send to areas within a nation or region needing water through the use of new and existing pipelines and water transportation systems (Aburizaiza, 2015).

An important method to deal with water scarcity is through education. This entails educating farmers, policymakers, businesses, and households how to best use and conserve water in order to lessen the problem the world faces today. Education can stimulate new ideas and ways of thinking that could lessen this burgeoning dilemma and hopefully bring about new solutions that many will benefit from.

Probably the most used method that has far reaching impact on water scarcity is water recycling. Water recycling can be used for multiple non-drinking purposes whether it is for agriculture, maintaining landscapes, or green zones. Water recycling can help relieve the stress on finding new sources of water and ultimately deciding where to use it. Water recycling can help reduce the amount of both treated and non-treated effluent into the environment, depositing organic and inorganic nutrients, such as nitrogen and phosphate, into water systems, that may be the reason for eutrophication and algal blooms while severely degrading existing bodies of water (Aburizaiza, 2015). Reusing water can help reduce the possibility of polluting rivers, streams, and lakes and help the rest of the environment. This can be used by businesses to not only promote social responsibility, but also reduce costs. For example, a PepsiCo Frito-Lay plant in Casa Grande, Arizona, is reported as being the first American food processing plant that can produce drinking-quality process water for reuse (Paulson, 2015). Frito-Lay's snack food manufacturing plant used for processing potatoes and corn has a $2,460 \mathrm{~m}^{3}$ per-day process water recovery treatment system which allows the firm to reduce its annual water usage by $378,541 \mathrm{~m}^{3}$ (Paulson, 2015).

Another way to help reduce water scarcity is the use of advanced technology for conservation purposes. Technology has made great leaps and bounds in recent years in a variety of fields and could be used to enhance and make efficient irrigation systems, water recycling and harvesting, agricultural technologies using less water, and desalination processes. Advanced technology is already being used by household appliance makers in order to reduce the use of water along with energy savings when designing new 
products (Hodgson, 2010). Currently advances in desalination technology has helped nations with their water scarcity problem. For example, in MENA due to declining costs and rapid growth in capacity, desalinated water is becoming ubiquitous, supplying more than 50 percent of the region's municipal water needs, to the point where nations such as the United Arab Emirates (UAE) are constructing the world's largest subterranean reservoir of desalinated water in order to safeguard supplies (Devlin, 2014).

Water scarcity can also be reduced by improving farming practices on a global basis. Agriculture is an extremely large user of water and there has been a great deal of water wasted in farming. For example, according to information from the California Department of Water Resources, 43 percent of that state's farmland in 2010 used some form of gravity irrigation which is regarded as the least efficient flood irrigation method since it uses large amounts of fresh water and there is much loss in the process (Tabarrok, 2015). Also, in MENA there are poor agricultural technologies which allows farming to be the major consumer of water sources in the region (Hussein, 2011). Due to this inefficiency (between 37 and 53 percent), poor farming techniques has caused a wide spectrum of problems including water logging salinity, low productivity, soil infertility, and deteriorating ground water quality (Hussein, 2011). On a global scale, it is estimated that the average world irrigation efficiency is approximately 50 percent in the years 2005 to 2007 which means that one-half of water withdrawal is lost between the source and its destination (Hertel \& Liu, 2016).

There are numerous other methods to lessen water scarcity such as improving sewage and sanitation systems and having clean water initiatives. If all of these methods were put into use on the scale necessary, then water scarcity would not be the problem that many nations face today. This ultimately means that not only would people have water globally, but that financial resources could be used to help nations in other ways. But this requires cooperation between various groups, from farmers to corporations to governments to policymakers to households. Until this happens, water scarcity will continue to be a major global problem.

\section{References}

Aburizaiza, O., Carpentar, D., DeNicola, E., Khwaja, H., \& Siddique, A. (2015). Climate Change and Water Scarcity: The Case of Saudi Arabia, 342-353.

Arab Human Development Report. (2009). Challenges to Human Security in the Arab Countries. United Nations Development Programme.

Association of State and Territorial Health Officials. (2015). Issue Brief. ASTHO, 1-6.

Cartwright, A., Orr, S., \& Tickner, D. (2009). Understanding Water Risks. World Wildlife Security Series Number 4, 1-40.

Chowdhury, J. (2008). The Harsh Economics of the Global Water Crisis. Alternet, 1-7.

Desperate measures: Rivers are disappearing in China. Building canals is not the solution. (2013). The

Economist, 1-3. 
Devlin, J. (2014). Is Water Scarcity Dampening Growth Prospects in the Middle East and North Africa? The Brookings Institution, 1-11.

Douglas, A. (2015). A Drought for Business: How Water Shortages Will Impact Your Bottom Line (pp. 9-11). Retrieved from http://www.business.com/finance/

Drewes, J. E., Garduno, C. P. R., \& Amy, G. L. (2012). Water reuse in the Kingdom of Saudi Arabia: Status, Prospects, and Research needs. Water Science Technology Water Supply, 926-936. https://doi.org/10.2166/ws.2012.063

Five Consequences of a Global Water Shortage. (2015). Seametrics, 1-3.

Fogden, J., \& Wood, G. (2009). Access to Safe Drinking Water and Its Impact on Global Economic Growth. HaloSource, 1-66.

Global Water Shortage: Water Scarcity and How to Help. (2016). The Water Project, 1-4.

Heinrich, M., \& Pedraza, L. E. (2016). Water Scarcity: Cooperation or Conflict in the Middle East and North Africa? Foreign Policy Journal, 1-12.

Hertel, T. W., \& Liu, J. (2016). Implications of water scarcity for economic growth. OECD Environment Working Papers No. 109, 1-56. https://doi.org/10.1787/5j1ss1611r32-en

Hertel, T. W., Liu, J., Ringler, C., Taheripour, F., \& Zhu, T. (2013). Water Scarcity and International Agricultural Trade. Agricultural and Applied Economics Association, 1-29.

Hodgson, A. (2010). Global water shortages will pose major challenges. Euromonitor, 1-14.

Hoekstra, A. (2014). Water Scarcity Challenges to Business. Scientific American, 1-11. https://doi.org/10.1038/nclimate2214

Hoekstra, A. Y., \& Mekonnen, M. M. (2016). Four Billion People Facing Severe Water Scarcity. Science Advances, 1-6.

Hooley, L. (2016). World Bank Report: The Effect of Water Scarcity on Economic Growth. World Bank Report, 1-5.

Hussein, M. A. (2011). Impacts of Water Scarcity on the Social Welfare of Citizens in the Middle East. Middle East Institute, 1-5.

Jena, M. (2016). Water Scarcity Could Impact West Asian Credit Ratings. Global Issues, 1-4.

Khan, D. (2015). Pakistan's water shortage creates dangerous agriculture conditions. CCTV America, $1-7$.

Klepper, G., \& Sonja, P. (2007). Potential impacts of water scarcity on the world economy. Global Change: Enough water for all? 263-267.

Muta'a Hellandendu, J. (2012). Health Implications of Water Scarcity in Nigeria. European Scientific Journal, 111-117.

Odhiambo, G. O. (2016). Water Scarcity in the Arabian Peninsula and socio-economic implications. Applied Water Science, 1-13. https://doi.org/10.1007/s13201-016-0440-1

Paulson, L. D. (2015). What is Water Scarcity? RWL Water, 1-7.

Repetto, R. (2012). Economic and Environmental Impacts of Climate Change in Nevada. Dēmos, 1-6.

Published by SCHOLINK INC. 
Ross, S. (2016). The Economic Effect of Water Shortages. Investopedia, 1-2.

Sahai, A. (2016). Economic Consequences of Water Scarcity. The Mackenzie Institute, 1-7.

Tabarrok, A. (2015). The Economics of the California Water Shortage. Marginal Revolution, 1-3.

Tickner, D. (2016). The silent crisis: Global water scarcity reshaping future foreign policy. The Foreign Policy Centre, 1-4.

Water Scarcity. (2016). Wikipedia, 1-22.

Water Scarcity. (2016). World Wildlife Fund, 1-7.

World Economic Forum. (2011). Water Scarcity. Island Press.

Yemen's Looming Water Crisis. (2014). Stratfor, 1-7.

Young, E. (2001). Global Population to Peak in 2070. New Scientist, 543. 